Marmaduke Pickthall 


\title{
Muslim Minorities
}

\author{
Editorial Board \\ Jørgen S. Nielsen (University of Copenhagen) \\ Aminah McCloud (DePaul University, Chicago) \\ Jörn Thielmann (Erlangen University)
}

VOLUME 21

The titles published in this series are listed at brill.com/mumi 


\title{
Marmaduke Pickthall
}

Islam and the Modern World

\author{
Edited by \\ Geoffrey P. Nash
}

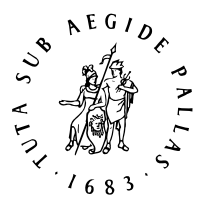

B R I L L

LEIDEN | BOSTON 
B R I L L This is an open access title distributed under the terms of the CC-BY-NC License,

O P E N which permits any non-commercial use, distribution, and reproduction in any

medium, provided the original author(s) and source are credited.

An electronic version of this book is freely available, thanks to the support of libraries working with Knowledge Unlatched. More information about the initiative can be found at www.knowledgeunlatched.org.

Cover illustration: Marmaduke Pickthall, in Islamic Review of February 1922.

The cover photo is reproduced by kind permission of the Ahmadiyya Anjuman Isha'at Lahore (UK) www.wokingmuslim.org

Library of Congress Cataloging-in-Publication Data

Names: Nash, Geoffrey, editor.

Title: Marmaduke Pickthall : Islam and the modern world / edited by Geoffrey

P. Nash.

Description: Leiden ; Boston : Brill, [2017] | Series: Muslim minorities ; V.

21 | Includes bibliographical references and index.

Identifiers: LCCN 2016034180 | ISBN 9789004327580 (hardback : alk. paper)

Subjects: LCSH: Pickthall, Marmaduke William, 1875-1936. | Muslims--Great

Britain--Biography. | Authors, English--2oth century--Biography.

Classification: LCC BP80.P53 M37 2017 | DDC 297.092 [B] --dc23

LC record available at https://lccn.loc.gov/2016034180

Typeface for the Latin, Greek, and Cyrillic scripts: "Brill”. See and download: brill.com/brill-typeface.

ISSN 1570-7571

ISBN 978-90-04-32758-0 (hardback)

ISBN 978-90-04-32759-7 (e-book)

Copyright 2017 by the Editors and Authors.

This work is published by Koninklijke Brill NV. Koninklijke Brill NV incorporates the imprints Brill, Brill Hes \& De Graaf, Brill Nijhoff, Brill Rodopi and Hotei Publishing.

Koninklijke Brill NV reserves the right to protect the publication against unauthorized use and to authorize dissemination by means of offprints, legitimate photocopies, microform editions, reprints, translations, and secondary information sources, such as abstracting and indexing services including databases. Requests for commercial re-use, use of parts of the publication, and/or translations must be addressed to Koninklijke Brill NV.

This book is printed on acid-free paper and produced in a sustainable manner. 


\section{Contents}

Foreword: Pickthall after 1936 VII

Peter Clark

Acknowledgement XIV

Introduction: Pickthall, Islam and the Modern World 1 Geoffrey P. Nash

PART 1

Pickthall and the British Muslim Community

1 Pickthall, Muslims of South Asia, and the British Muslim Community of the Early $1900 \mathrm{~s} \quad 23$

K. Humayun Ansari

2 Marmaduke Pickthall and the British Muslim Convert Community

47 Jamie Gilham

3 Abdullah Quilliam (Henri De Léon) and Marmaduke Pickthall:

Agreements and Disagreements between Two Prominent Muslims in the London and Woking Communities 72

Ron Geaves

PART 2

Pickthall's Religious and Political Thought

4 Pickthall's Anti-Ottoman Dissent: The Politics of Religious

Conversion 91

Mohammad Siddique Seddon

5 Pickthall's Islamic Politics 106

M.A. Sherif

6 Pickthall, Ottomanism, and Modern Turkey 137

Geoffrey P. Nash 
PART 3

Man of Letters, Traveller and Translator

7 Oriental Eyes, or Seeing and Being Seen: Popular Culture and the Near Eastern Fiction of Marmaduke Pickthall 159

Andrew C. Long

8 A Vehicle for the Sacred: Marmaduke Pickthall's Near Eastern Novels $\quad 182$

Adnan Ashraf

9 Becoming Woman and Gender Typologies in Marmaduke Pickthall's Oriental Fiction 196

Faruk Kökoğlu

10 “Throwing Off the European": Marmaduke Pickthall's Travels in

Arabia 1894-96 216

James Canton

11 Muhammad Marmaduke Pickthall's English Translation of the Quran (1930): An Assessment 231

A.R. Kidwai

Index $\quad 249$ 


\title{
Foreword: Pickthall after 1936
}

\author{
By Peter Clark
}

Marmaduke Pickthall died on 19 May 1936 at the age of sixty-one. His widow, Muriel, invited Mrs Anne Fremantle, to write a biography. ${ }^{1}$

Anne Fremantle was born Anne Huth Jackson, the daughter of a wealthy banker and his wife, a daughter of the some time Liberal Member of Parliament, junior Minister and proconsul, the grandly named Sir Elphinstone Mountstuart Grant Duff. The Huth Jacksons had a London house and a massive country estate at Possingworth near Uckfield in Sussex. Mrs Huth Jackson was well-connected socially, and familiar with the political and literary elite of the capital. Anne, born in 1909, was a precocious child. At the end of the First World War the Pickthalls lived at Pond House, a cottage on the Possingworth estate. The young Anne and Marmaduke, then in his early forties, got to know each other and became great friends. We have only Anne's account of the friendship, but it seems Pickthall treated her as a young adult, and played the role of substitute father. Her own father had been busy and distant, and died in 1921, by which time the Pickthalls had moved to India. She was enchanted by his memories of his early travels in Palestine and Syria and the stories and legends he had picked up. She claimed to have become a Muslim as a young girl. ${ }^{2}$ When he went to India, it appears he regularly wrote to her with news of his life and encounters. She saw him on his periodic visits to Britain. He attended her marriage in London (conducted by the Archbishop of Canterbury), and during the last year of his life they saw each other after he had returned to England after ten years in Hyderabad.

Anne Fremantle was widely read and had already written a book on George Eliot at the age of twenty-three. She was active politically and stood as Labour candidate against Duff Cooper in a parliamentary election. She also, in 1961, wrote a history of the Fabian Society.

Although Muriel had asked Anne Fremantle to write the biography, Anne did not have a high opinion of Muriel. "She shared neither his faith nor his talents - he was a gifted and successful novelist - and seemed a meowing person, not happy in Sussex or later in India", she wrote uncharitably in her own autobiography. ${ }^{3}$ It was as if Anne wanted to have exclusive possession of Marmaduke and was the only woman to understand him.

1 Anne Fremantle, Loyal Enemy (London: Hutchinson, London, 1939).

Anne Fremantle, Three-Cornered Heart (London: Collins, 1971), 197.

3 Fremantle, Three-Cornered Heart, 168. 
Anne Fremantle destroyed many of the most personal and most interesting of the letters Pickthall wrote to her, on the insistence of her husband. She had difficulties in gathering further material. She wrote to a relation of Pickthall that "Marmaduke is a most elusive person to get facts or material about".

Her book, Loyal Enemy, was published by Hutchinson in January 1939. It was widely reviewed. Harold Nicolson ${ }^{5}$ did not agree with most of Pickthall's public views but recognised that Anne Fremantle's "girlish hero-worship" was not misplaced. Pickthall, in spite of alienation from Britain and Christianity, "remained sweet, selfless and unassuming to the end". A G MacDonell reviewed the book in The Observer, ${ }^{6}$ acknowledging Pickthall's "extraordinary character". But the significance of the book and the memory of Pickthall were probably smothered by the more pressing concerns of the war. A more sensational review in The Sunday Dispatch, ${ }^{7}$ opened with the words, "He was a small, mild, moustached, quietly-spoken Englishman, but Mr Marmaduke Pickthall had a cause which made him a lion among men". None of these reviews reflected on the significance of an Englishman throwing himself so unreservedly into the world of Islam.

The book was long - 441 pages - and is an intimate personal portrait of a modest, shy man who was able to communicate with a bright child who, in turn, hero-worshipped him. However it seems to have been hastily written. It sprawls and, although letters and articles are quoted - sometimes at length - there are no references. The book is poorly edited and proofread. Jaffa and Jedda are mixed up. The transliterations of Arabic are sometimes erroneous, sometimes eccentric.

Anne Fremantle mentions that she was given the original manuscript of The Meaning of the Glorious Koran. Indeed he had translated some of its verses for her when she was a child. Anne Fremantle lived for another sixty years after Loyal Enemy, much of the time in the United States. When in the early 1980 s I was preparing my book on Pickthall, I wrote to her asking about any letters and papers. She replied to me in October 1983 saying she had sent them to "Hyderabad because I thought they may be included in a collection of his works". She was unable to help about the location of other personal papers of the man she described to me as "my greatest friend from my father's death when I was 12 until his own death".

4 Anne Fremantle to Mrs Beasley, 8 August 1936, in possession of Sarah Pickthall.

5 "From an English Vicarage to the Moslem Faith," The Daily Telegraph, January 6, 1939.

6 The Observer, 8 January 1939.

7 Sunday Dispatch, 8 January 1939.

8 Anne Fremantle to Peter Clark, 17 October 1983. 
In 1992, six years after the publication of my own book, ${ }^{9}$ I was in Hyderabad. One of Pickthall's Hyderabad friends had been a historian, Farouk Sherwani. When Pickthall finally left Hyderabad in 1935 Farouk went with Pickthall to the station, accompanied by his young son, Mustafa. It was Mustafa who was my guide in Hyderabad and we called on other elderly gentlemen who had known Pickthall. I asked about personal papers. "Pickthall had no interest in personal possessions", Mustafa told me. "He would have arrived in Hyderabad with one suitcase; he would have left with one suitcase".

Pickthall is rightly best remembered as the author of The Meaning of the Glorious Koran. First published by Knopf in New York in 1930 it has gone through many reprints in various countries. In 1938 the Government Central Press, Hyderabad, brought out an edition with the Arabic text and the English alongside each other. This is how Pickthall wanted his work to appear. In 1970 a Delhi publisher produced a three language version ${ }^{10}$ with Urdu, Arabic and English. Ten years later, under the patronage of the Ruler of Sharjah, Sheikh Sultan bin Muhammad Al Qasimi, a series of cassettes was made of Pickthall's translation, recited by Gai Eaton (Hasan Abdul Hakim).

The lectures on Islam that Pickthall delivered in Madras (Chennai) in 1925 have also been reprinted periodically in both India and Pakistan. ${ }^{11}$

I first became fascinated in the life and work of Marmaduke Pickthall in the late 1970s. I had lived in Jordan and Lebanon and knew Damascus; when I read Saïd the Fisherman I was bowled over by it. I could not put it down. Every page scintillated with insight. I liked the way he used dialogue, translating colloquial Syrian Arabic literally into English. I appreciated the way he seemed to create a distinctive language in which he described the lives of unspectacular Syrians and Palestinians, without sentimentality or romance. His realistic and sympathetic word-portraits of ordinary people reminded me of the writings of Sir Walter Scott and Thomas Hardy. I read Edward Said's Orientalism when it was published in 1978 and was appalled that Pickthall's work was dismissed alongside that of Pierre Loti as "exotic fiction of minor writers". ${ }^{12}$ I wondered

$9 \quad$ Peter Clark, Marmaduke Pickthall: British Muslim (London: Quartet, 1986).

10 The Meaning of the Glorious Koran, with Urdu translation by Fateh Muhammad Jallendhri, (Delhi: Kutubkhana Ishaat-ul-Islam, 1970).

11 For example, as Islamic Culture (Lahore: Ferozsons, 1958), and as The Cultural Side of Islam (New Delhi: Kitab Bhavan, 1981).

12 Edward Said, Orientalism: Western Conceptions of the Orient (London: Routledge and Kegan Paul, 1978), $25^{2}$. 
whether Edward Said had actually read any of Pickthall's Middle Eastern fiction.

I looked out for more of his novels and soon came across The Children of the Nile, Oriental Encounters and The Valley of the Kings. They all had a similar quality of empathetic realism. I then made a determined effort to find the rest of his work, including those novels of his that were located in England. One book-seller told me that they were unsellable and some dealers just pulped them as they blocked up valuable shelf-space. I succeeded in collecting them all and read them. I had been lucky in my introduction to Pickthall's novels for the first four I bought and read were also his best. I also acquired Loyal Enemy and although a vivid and loving personal portrait of the man comes through, I thought Anne Fremantle had missed Pickthall's literary and political significance. I thought there was something gushing and jejune about her approach. Here was a man whose work was celebrated by such a varied range of demanding critics as H G Wells, D H Lawrence and E M Forster, had a best-seller with Saïd the Fisherman, but was overlooked in the standard works of twentieth century literary history. I also thought Anne Fremantle did not appreciate Pickthall's significance as a twentieth century Muslim intellectual. So I decided to write my own book about him.

I wrote it while working as a Director of the British Council in Yemen and Tunisia. I advertised for information on any personal papers, wrote to the Osmania University and the Andhra Pradesh State Archives in Hyderabad, but drew a blank. I also wrote to the Karachi (Pakistan) newspaper, Dawn. (I knew many old Hyderabadis had migrated to Karachi after the "Police Action" that absorbed the Nizamate into independent India.) I had several answers which I used in my own book. Anne Fremantle told me that she did not think Marmaduke's brother Rudolph had any descendants. In this she was wrong. In 1983 I did write out of the blue to a Pickthall in London but never had a reply. The letter was, however - I learned thirty-two years later - passed on to a granddaughter in law of Rudolph. She never replied to me and her daughter, Sarah Pickthall, showed me the letter in 2015. Of the twelve children begotten by Pickthall's father, only three had children of their own. Apart from Rudolph's only son, there were two grand-daughters, both of whom were childless. One was Marjorie Pickthall, whose father had emigrated to Canada: Marjorie became a well-known Canadian novelist. The other was a historian of Lincolnshire, Mrs Dorothy Rudkin, who died in 1984. She had kept some family photographs and, by the kindness of her executor, Dr Robert Pacey, I was able to use three of these in my book. The other major source I used - which Anne Fremantle did not to the same degree - was Pickthall's own journalism, especially articles he wrote for Islamic Review, New Age and Islamic Culture. There were many 
autobiographical allusions in these articles, and many links with his fiction. Sometimes an event in the journalism was transposed into one of his novels.

In many ways my book complemented Loyal Enemy. When I reread it I think the terse style reflects the kind of extended writing that was part of my training. It has the flavour of both a $\mathrm{PhD}$ thesis and a civil service minute. There is a terseness in style, a shunning of ornamental or superfluous prose. My aim was to draw attention to an outstanding (but neglected) twentieth century writer. Pickthall was a man I hugely admired, though I shared none of his intellectual positions. I did however appreciate his insight into the Arab Middle East and knew of no other English writer to match him. He lacked the selfcentredness of Burton and Blunt; he was more accessible than Lane. I did not have the resources of university support or academic networks. I was either too busy, too idle or too impatient to pursue lines that may have led to greater information. If anyone was interested in Pickthall they would read both Anne Fremantle's book and mine.

As well as publishing my book, Quartet Books also reissued Pickthall's best novel, Saïd the Fisherman. Both were published in May 1986 on the fiftieth anniversary of his death. On the same day I inserted an In Memoriam notice in The Times.

There were some reviews in the London papers. W B Hepburn, in The Daily Telegraph, ${ }^{13}$ thought the book "too laconic" though I showed an "infectious partiality" for Pickthall. Malise Ruthven in the Times Literary Supplement ${ }^{14}$ noted that in "his Eastern novels he weaves Arabic words and sentence-constructions into a language which is stylized, though less mannered than Doughty's. Drawing on a vast repertoire of folklore and anthropological observation, he seems to enter effortlessly into an Eastern vernacular and into the skins of his Eastern characters without sentimentality or condescension".

There was more notice of the book in specialist journalism, relating to Islam or the Middle East. Michael Adams, in Middle East International, ${ }^{15}$ thought Marmaduke Pickthall had "disappeared into undeserved oblivion" and hoped my book would "put him back on the literary map". Asaf Hussain in The Crescent, ${ }^{16}$ in a long and generally appreciative article, was critical of Pickthall's views on the Prophet Muhammad and war, and also thought that I - apparently - believed "like all westerners...that man is born out of sin and that no good can come out of him without some ulterior motive". It was wrong

\footnotetext{
13 The Daily Telegraph 19 September 1986.

14 Times Literary Supplement 5 September 1986.

15 Middle East International, 20 February 1987.

16 The Crescent, 16-31 August 1986.
} 
to think that Pickthall's fascination with the Middle East and his ultimate conversion was the result of personal failure. There were also reviews in the English language newspapers of the Gulf and Israel.

Three years after the publication of Marmaduke Pickthall: British Muslim in 1986, Salman Rushdie's Satanic Verses was published. If my book had been published that year it might have added to an informed discussion about the ethics of the Muslim as novelist or the novelist as Muslim. But my book was already being remaindered.

My book was occasionally quoted, and Pickthall's significance was recognised in works such as "The Infidel Within": Muslims in Britain since 1800 by Humayun Ansari ${ }^{17}$ and the work of Geoffrey Nash. ${ }^{18}$ The former acknowledges him as a Muslim intellectual, the latter as a writer.

But it has been in the last ten years that there has been a steady acceleration of interest in the life and work of Marmaduke Pickthall; this volume is a climax of that growing interest. He is now getting into reference works. Muhammad Shaheen contributed an article for the Oxford Dictionary of National Biography, $(O D N B)$ published in 2007. ODNB is now published on-line. Pickthall has many references on the worldwide web. He is celebrated in the British Muslim community and there is a Pickthall Academy in Camden in London.

In 2012 the BBC made a film about Pickthall and two of his contemporaries who also embraced Islam - Lord Headley and Abdullah Quilliam. ${ }^{19}$ Marmaduke's great great niece, Sarah Pickthall, took part in that film (as I did). Her family had regarded the man with a mixture of pride and reticence, but Sarah is doing what she can to celebrate his name. The film was shown late at night during Ramadan and there were 700,000 viewers. It was later transmitted on ввС international channels. Friends in Dubai and Vancouver told me they had seen it. In 2014 two books had extended chapters on Pickthall. Andrew C Long in Reading Arabia: British Orientalism in the Age of Mass Publication $1880-1939^{20}$ places Pickthall as a travel writer in the context of his contemporaries. Jamie Gilham in Loyal Enemies: British Converts to Islam, $1850-1950^{21}$ has worked through papers at the Public Records Office and letters Pickthall wrote to Aubrey Herbert to give a good account of Pickthall's First World War activities.

\footnotetext{
17 Humayun Ansari, "The Infidel Within": Muslims in Britain since 1800 (London: Hurst, 2004).

18 Geoffrey P. Nash, From Empire to Orient: Travellers in the Middle East 1830-1926 (London: I.B. Tauris, 2005).

19 Great British Islam, 18 July 2012.

20 Andrew C Long, Reading Arabia: British Orientalism in the Age of Mass Publication 1880-1930 (Syracus: Syracuse University Press, 2014).

21 Jamie Gilham, Loyal Enemies, British Converts to Islam 1850-1950 (London: Hurst, 2014).
} 
In 2010 the Muslim Academic Trust reissued The Early Hours, the Turkey novel, first published in 1921, with a thirty page biographical sketch by Abdal Hakim Murad, the imam of the University of Cambridge. (As Tim Winter he had helped me with my book.)

The Saudi scholar, Ahmad al-Ghamari, wrote a thesis on Pickthall for a United States university and is currently translating my book into Arabic. The thesis assesses him as a novelist and was registered in a Literature faculty.

The British publisher, Beacon Books, is reprinting some of Pickthall's Middle Eastern novels and also, in one volume, the twenty-eight Middle Eastern short stories. The same publisher is reprinting Marmaduke Pickthall:British Muslim.

The revived interest in Pickthall has been stimulated by a new twenty-first century identity politics. The terrorist events of 11 September 2001 in New York and of 7 July 2005 in London, committed in the name of Islam, have challenged Muslims. It has been regrettably easy to demonise Islam, to the anger and distress of most Muslims. Islam is presented in some of the British press as a violent alien creed. But Pickthall was quintessentially English, conservative in behaviour as well as in politics. He was passionate in his commitment, an intellectual leader. His story challenges the negative stereotypes of much popular press comment. Although rooted in Britain he was a man of a global perspective. Moreover in his writings he was liberal, seeing Islam as open, tolerant and progressive - again in contrast to many of the stereotypes. And as the reviewers of Anne Fremantle's book in 1939 observed, he had an extraordinary life. In his 1923 essay, "Salute to the Orient", E M Forster wrote in praise of Pickthall's Near Eastern fiction. He was, Forster said, "a writer of much merit who has not yet come into his own."22 It may be that Pickthall's time at last has arrived.

\author{
Dr Peter Clark OBE \\ June 2016
}

22 E M Forster's essay appears in Abinger Harvest, Harmondsworth: Penguin Books, 1967, 275-91. (The book was first published by Edward Arnold in 1936.). 


\section{Acknowledgement}

The cover photo is reproduced by kind permission of the Ahmadiyya Anjuman Isha'at Lahore (UK) www.wokingmuslim.org 